Foss. Rec., 21, 291-299, 2018

https://doi.org/10.5194/fr-21-291-2018

(C) Author(s) 2018. This work is distributed under

the Creative Commons Attribution 4.0 License.

\title{
First occurrence of Duboisia (Bovidae, Artiodactyla, Mammalia) from Thailand
}

\author{
Yuichiro Nishioka $^{1}$ and Chavalit Vidthayanon ${ }^{2}$ \\ ${ }^{1}$ Waseda Institute for Advanced Study, Waseda University, Shinjuku, 169-8050, Japan \\ 2independent researcher: Bangkok, 10900, Thailand
}

Correspondence: Yuichiro Nishioka (nishioka@aoni.waseda.jp)

Received: 10 May 2018 - Revised: 12 August 2018 - Accepted: 4 October 2018 - Published: 24 October 2018

\begin{abstract}
The first fossil record of Duboisia (Boselaphini, Bovidae) from Thailand confirms that this genus is no longer endemic to Java, Indonesia. The new fossil material is a calvarium with horn cores (older than the Middle Pleistocene) collected from a sandpit at Tha Chang, Nakhon Ratchasima Province, north-eastern Thailand. The present specimen is provisionally allocated to a species of Duboisia aff. D. santeng, which has weaker precornual ridges and anterior keels on the horn cores than $D$. santeng from Early and Middle Pleistocene deposits of Java, but these species share basic characteristics of horn cores as follows: the lower half inclined backwards; the upper half curved upwards; cross section rounded triangular, antero-posteriorly compressed, and with medial and lateral keels. Morphological similarities between $D$. aff. santeng and $D$. santeng support a strong faunal interchange between continental South East Asia and Java before the Middle Pleistocene, and suggest that the genus Duboisia diverged from the other genera of Boselaphini in the "Siva-Malayan" region.
\end{abstract}

\section{Introduction}

South East Asia is geographically divided from the Indian subcontinent by the Himalayan-Tibetan Plateau, the IndoBurma Range, and the Ganges and Brahmaputra rivers. These barriers form a zoogeographical boundary for terrestrial mammals between the Indo-Chinese and Indian subregions (Corbet and Hill, 1992). The Neogene fauna of continental South East Asia is similar to that of the Siwaliks, in the Indo-Pakistan area (e.g. Stamp, 1922; Colbert, 1938), but recent studies based on mammalian fossils from the Irrawaddy beds (Middle Miocene to Early Pleistocene) of Myanmar have demonstrated a faunal difference between the Siwaliks and Irrawaddy beds, which had increased since the Late Miocene or Early Pliocene due to forming zoogeographical barriers (Nishioka et al., 2015, 2018b; Takai et al., 2016).

Mammalian endemism in South East Asia had increased during the Plio-Pleistocene (e.g. Van den Bergh et al., 2001; Van der Geer et al., 2010). The latest Pliocene and Early Pleistocene Satir fauna from Java, Indonesia, is impoverished and unbalanced and includes mammals of "Siva-Malayan" origin, such as Hexaprotodon sivajavanicus (Hippopotamidae, Artiodactyla) and Sinomastodon bumiajuensis (Proboscidea) (Sondaar, 1984). These mammals have been traditionally believed as endemic species to Java (Van der Maarel, 1932; Hooijer, 1950), but to what degree island species differ from the original continental species from the Siwaliks and the Irrawaddy beds is insufficiently studied (Van der Geer et al., 2010).

The "Stegodon-Homo erectus fauna" from the EarlyMiddle Pleistocene of Java (e.g. Trinil HK and Sangiran dome) is characterized by a relatively low degree of endemism and is composed of Siwalik species such as Pachycrocuta brevirostris (Carnivora) and Javanese species such as Stegodon trigonocephalus (Proboscidea) derived from mammals of the "Siva-Malayan" origin (Van der Geer et al., 2010). Duboisia santeng is an endemic species of Boselaphini (Bovidae, Artiodactyla) in the Early-Middle Pleistocene fauna of Java, which represents a somewhat isolated environment (Hooijer, 1958; Aimi and Aziz, 1985; Van den Bergh et al., 2001; Rozzi et al., 2013). D. santeng is phylogenetically related to living Indian boselaphins, Boselaphus tragocamelus and Tetracerus quadricornis (Stremme, 1911; Pilgrim, 1939; Hooijer, 1958). However, when a putative ancestor of $D$. santeng colonized Java is still debatable (Rozzi 
et al., 2013), owing to the absence of certain fossil evidence on continental South East Asia to show a relationship between Javanese $D$. santeng and Indian Boselaphini.

Out of Java, Moigne et al. (2016) reported three isolated teeth belonging to the genus Duboisia from the Upper Pliocene Masol Formation of the Siwaliks, India, although they did not mention detail morphological comparisons on the basis of apomorphic characteristics of each taxon. The presence of Duboisia in continental South East Asia was mentioned by Hooijer (1962), based on some dental and postcranial remains from Quaternary cave deposits at Tambun, Peninsular Malaysia. However, we are not sure if this identification is valid because of the fragmentary nature of the remains. Furthermore, all specimens of $D$. santeng in the Hooijer collection are missing (Lim, 2013). A partial cranium of Duboisia was recently found from central Myanmar (but without geological context), which gives preliminarily evidence suggesting the existence of the genus on continental South East Asia (Nishioka et al., 2018b). In the present study, we describe the first specimen of Duboisia from Thailand. The specimen is a skull with complete horn cores that are useful for taxonomic comparisons of Duboisia remains between continental and island specimens from South East Asia.

\section{Geological settings}

The Tha Chang sandpits $\left(15^{\circ} 05^{\prime} \mathrm{N}, 102^{\circ} 20^{\prime} \mathrm{E}\right)$ are located $22 \mathrm{~km}$ east of Nakhon Ratchasima (or Khorat) City, northeastern Thailand (Fig. 1). More than 10 sandpits have been mined since 1985 and have exposed Neogene and Quaternary fluvial deposits along the Mun River, a tributary of the Mekong River. One of the fossil localities, Tha Chang sandpit no. 8 (or Somsak sandpit), is well-known for its yield of Miocene orangutans, Khoratpithecus piriyai (Chaimanee et al., 2004). The sediments at sandpit no. 8 are an exposed outcrop of about $30 \mathrm{~m}$ depth from the ground to the bottom when the sandpit was first mined (Shinji Nagaoka, personal communication, 2002; see also Thasod et al., 2011).

Sediments at sandpit no. 8 have been divided into two units: a lower unit of organic greyish sand and gravel, and an upper unit of yellowish sand (Chaimanee et al., 2006, 2007). The basal part of the lower unit overlies on the Mahasarakham Formation including the evaporitic layer around 40 or $50 \mathrm{~m}$ depth (Chaimanee et al., 2006). The lower unit is formed by grey conglomeratic sandstone with some thin silt and clay layers. The sandstone shows clear cross-bedding, suggesting channel deposits, and contains abundant fossils of tree trunks, leaves and vertebrate animals. The upper part of the lower unit is characterized by the inclusion of peat (ca. $0.5 \mathrm{~m}$ thick) and gravel layers (ca. $0.5-1 \mathrm{~m}$ thick) around $10 \mathrm{~m}$ depth from the ground. Plant fossils have been found in all layers.
The upper oxidized unit starts from about $8 \mathrm{~m}$ depth from the ground, based on the stratigraphic column by Chaimanee et al. (2006). Some tektites have been collected from the lowermost part of the upper unit (ca. $8 \mathrm{~m}$ depth), which originate from the widespread tektite debris field at $0.8 \mathrm{Ma}$ in northeastern Thailand (Howard et al., 2003). Haines et al. (2004) estimated that the sediments of the Tha Chang sandpits are dated to Quaternary, because those tektites were also collected from the lower unit.

Mammalian fossils have been collected primarily from the lower unit. An isolated molar of the proboscideans Stegolophodon cf. stegodontoides and a skull of the anthracothere Merycopotamus thachangensis were collected in situ from the silt (ca. $13.5 \mathrm{~m}$ depth) and sandstone (ca. $18 \mathrm{~m}$ depth) layers of sandpit no. 8, respectively (Hanta et al., 2008; Thasod et al., 2011). Geological information for other mammalian fossils from the Tha Chang sandpits is unavailable, but most of them were probably from the lower unit because the fossils are covered by greyish sandstone with pyrite (iron sulfide).

To date, the mammalian fossil assemblage from sandpit no. 8 includes 4 orders, 11 families, and 21 genera: Primates (Khoratpithecus); Artiodactyla (Hippopotamodon, Propotamochoerus, Hexaprotodon, Merycopotamus, Microbunodon, Bramatherium and several species of bovids); Perissodactyla (Hipparion, Chilotherium, Brachypotherium, Alicornops and Aceratherium); and Proboscidea (Prodeinotherium, Deinotherium, Gomphotherium, Tetralophodon, Sinomastodon, cf. Protanancus, Stegodon, Stegolophodon and Elephas) (Chaimanee et al., 2004, 2007; Saegusa et al., 2005; Hanta et al., 2008; Thasod et al., 2011; Deng et al., 2013; Nishioka et al., 2014). Another sandpit (no. 10) near Takut Khon village also recovered a similar mammalian fossil assemblage including Zygolophodon (Duangkrayom et al., 2017). The previous studies, as listed above, suggested that these genera are biostratigraphically correlated with those in the Dhok Pathan fauna (10.1 to ca. 3.5 Ma; Barry et al., 2002) from the Siwaliks, Indo-Pakistan. Chaimanee et al. (2006) strictly estimated the age of the lower unit being between 9 and $6 \mathrm{Ma}$ if hippos (Hexaprotodon) are absent in the fossil assemblage, and between 7.4 and $5.9 \mathrm{Ma}$ if hippos are present. However, proboscideans include both Neogene taxa (e.g. Prodeinotherium) and Quaternary taxa (e.g. Elephas) (Thasod et al., 2011). The fossil assemblage from sandpit no. 8 is most likely dated to the Late Miocene, but it sometimes includes several fauna from different ages owing to collection bias.

\section{Material and methods}

\subsection{Material}

The examined fossil specimen (PPN 01-000109) that is housed at the Sukhothai Elephant World Museum, Thai- 


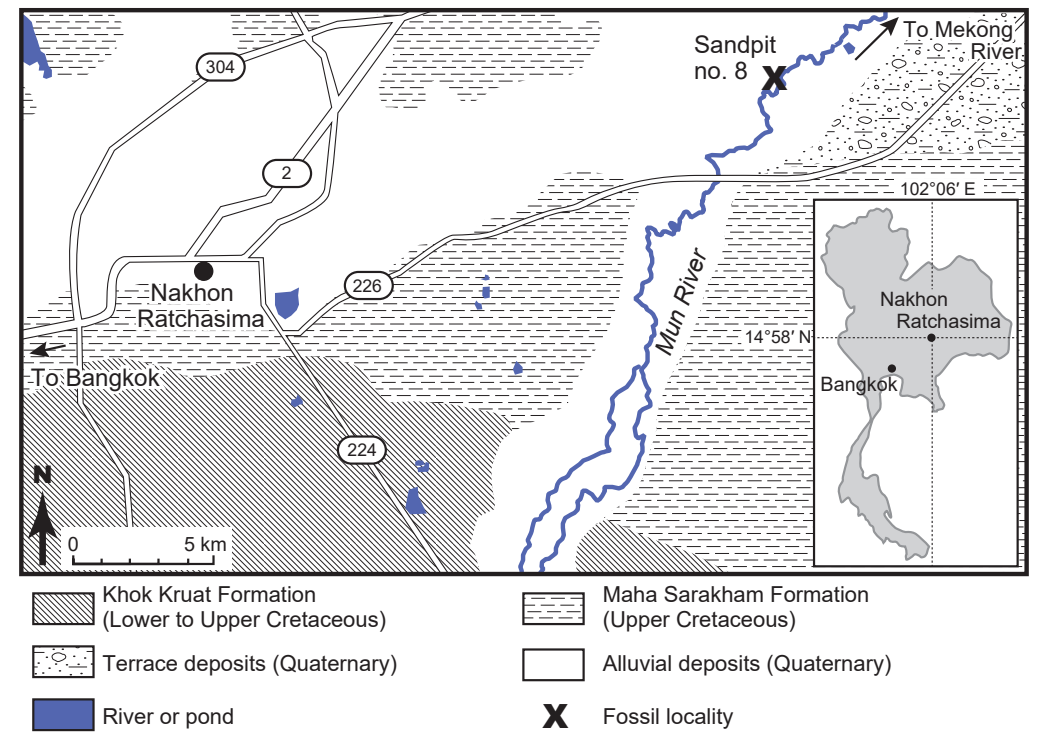

Figure 1. Geological map of the Khorat basin, Nakhon Ratchasima, north-eastern Thailand, and the locality of Tha Chang sandpit no. 8 (modified from Department of Mineral Resources, 1999).

land, was originally found in a private collection of Kamol Chaivanich in Bangkok. According to him, the specimen was collected from a sandpit in Tha Chang before 2007 when sandpit no. 8 was being mined. The fossil surface was originally covered by greyish sandstone with many pebble- or granule-sized gravel stones under $10 \mathrm{~mm}$ in diameter (Fig. 2). Gravel layers at Tha Chang sandpit no. 8 lie between 7 and $14 \mathrm{~m}$ depth from the ground, which includes both upper and lower units (Chaimanee et al., 2006). A combination of accompanying both greyish sandstone with pyrite and many pebbles on the fossil surface indicates that this fossil might have been retrieved from the lower unit, similar to mammalian fossils from the Miocene rather than the Pleistocene.

PPN 01-000109 was compared with two skulls of Duboisia santeng from the Pleistocene of Java. One specimen (MGB.SA 290779) is a calvarium with right and left horn cores recovered from the Early-Middle Pleistocene deposits at Pucung, Sangiran Dome area (Aimi and Aziz, 1985). The other specimen (MGB.Dbs) on display at the same institute is a neurocranium with horn cores probably from Sangiran. Furthermore, we also referred to pictures of D. santeng skulls from Trinil, including the lectotype, which are housed at Naturalis Biodiversity Centre in Leiden, the Netherlands (Stremme, 1911; Hooijer, 1958; Tshen Tze Lim, personal communication, 2016). The other species belonging to Boselaphini used in this study were as follows: Boselaphus tragocamelus (BNHS 18183; 18185; 18186); Boselaphus namadicus (BMNH 36851 = holotype by Rutimeyer, 1878; M486) and Tetracerus quadricornis (BNHS 17986; 18125).

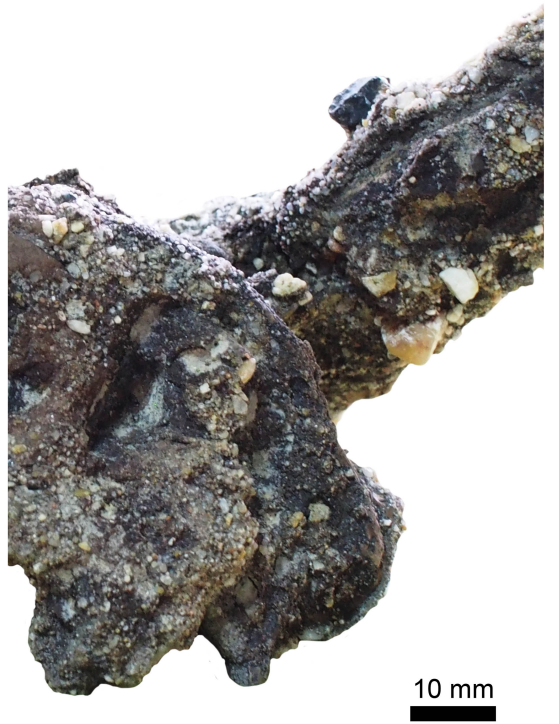

Figure 2. Posterior view (right side) of PPN 01-000109 before preparation.

\subsection{Institutional abbreviations}

BMNH, British Museum of Natural History (currently, Natural History Museum, London), UK; BNHS, Bombay Natural History Society, Mumbai, India; MGB, Museum Geologi Bandung, Java, Indonesia; PPN, Prasert Prasartthong-Osoth Natural, Sukhothai Elephant World Museum, Sukhothai, Thailand. 


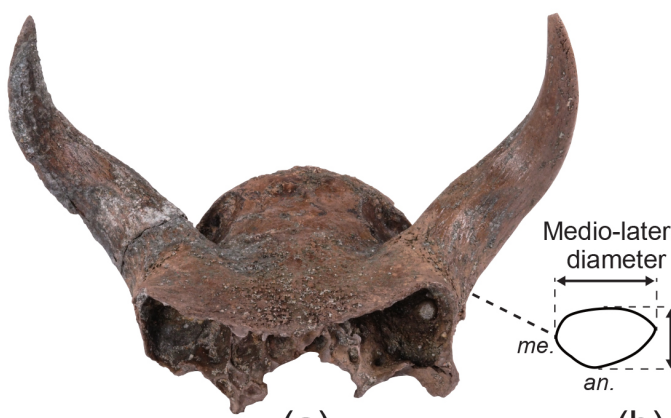

(a)

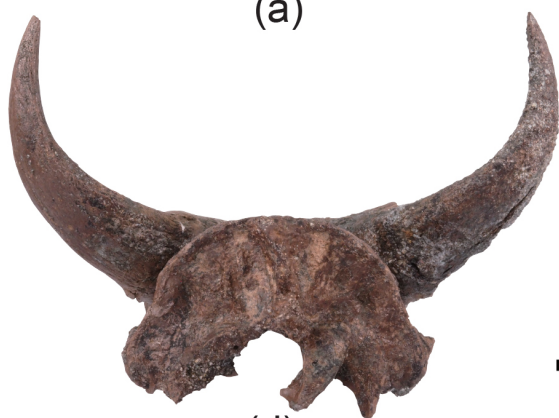

(d)

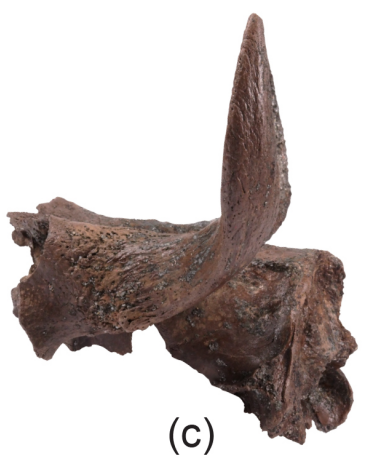

(c)

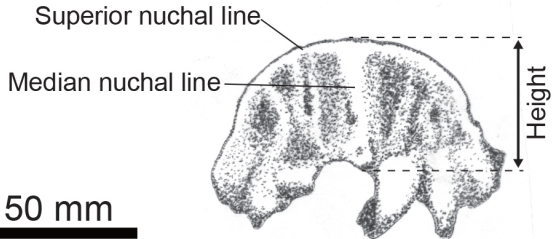

(e)

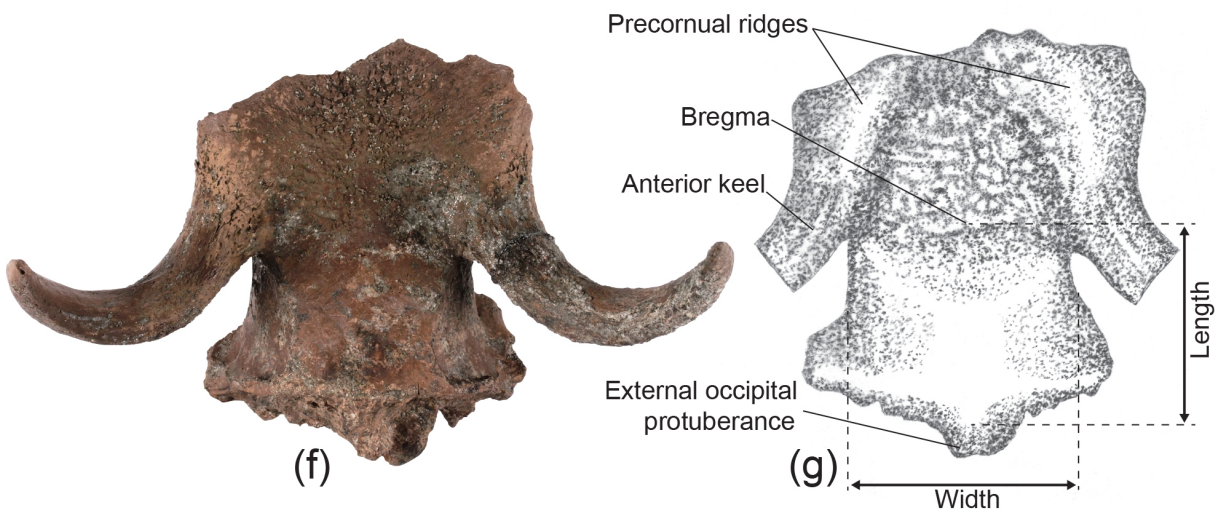

Figure 3. Calvarium with right and left horn cores of Duboisia aff. santeng (PPN 01-000109). (a) Anterior view; (b) cross section of the left horn core (an., anterior; me., medial.); (c) left lateral view; (d) posterior view; (e) schematic drawing of the posterior surface; (f) dorsal view; (g) schematic drawing of the dorsal surface.

\section{Systematic palaeontology}

Order Artiodactyla Owen, 1848

Family Bovidae Gray, 1821

Subfamily Bovinae Gray, 1821

Genus Duboisia Stremme, 1911

Duboisia aff. santeng (Dubois, 1891)

(Fig. 3)

Examined material: PPN 01-000109, a calvarium with right and left horn cores.

Locality: A sandpit at Tha Chang, Nakhon Ratchasima City, north-eastern Thailand.
Age: Younger than the Middle Miocene and older than the Middle Pleistocene.

Measurements: Antero-posterior diameter of the left horn core: $18.5 \mathrm{~mm}$; medio-lateral diameter of the left horn core: $33.6 \mathrm{~mm}$; length of brain case (between bregma and superior nuchal line): $65.1 \mathrm{~mm}$; maximum width of brain case: $68.7 \mathrm{~mm}$; height of the occipital without the foramen magnum: $38.1 \mathrm{~mm}$ (see also Table 1).

Description: The present specimen is a calvarium with complete right and left horn cores, including the frontal, parietal, temporal and occipital bones. The basioccipital part is broken. The dorsal surface on the fronto-parietal region is flat and faintly depressed. The frontal surface is 
rugose, with weak precornual ridges extending from the anterior ridge of the horn cores (Fig. 3g). Supraorbital foramina are not found on the preserved parts: that means they are situated further towards the front than the horn pedicels. The postero-dorsal rims of the orbits weakly project outwards. Temporal crests are moderately developed, slightly overhanging along the superior nuchal line on the occipital. The external occipital protuberance is projected posteriorly. The median nuchal line forms a sharp ridge and gently inclines below the centre. The brain case is squared in dorsal view (length/width $=0.95$ ). The height of the occipital without the foramen magnum is low relative to the brain-case width (height/width $=0.55$ ). The mastoid processes project laterally, with shallow squamosal shelves.

The horn cores insert caudolaterally from the orbits, strongly inclined backwards being parallel to the frontal surface at the base, and bend upwards at the middle part. In the antero-dorsal view (Fig. 3a), the horn cores diverge at an angle of $95^{\circ}$ at the base, and curve inwards after the middle part. The horn core is weakly twisted clockwise (right side). Right and left horn cores have a wide interval at the frontal surface $(56.0 \mathrm{~mm}$ between the medial keels). The cross section of the horn cores has a rounded triangular outline antero-posteriorly compressed (Fig. 4b). There are medial and lateral keels from the base to the top. The anterior surface is convex but does not have a clear keel.

Remarks: Most antelope-sized species of Bovinae were traditionally included in the tribe Boselaphini (McKenna and Bell, 1997). However, it is currently accepted that the tribe encompasses only the following crown genera: Boselaphus, Tetracerus, and Duboisia (Bibi, 2009; Bibi et al., 2009). There are some bovines whose taxonomic positions are formally pending. Schlosser (1903) proposed Paraboselaphus ameghinoi, referring to some isolated cheek teeth from China, but his materials and description are insufficient to define an independent taxon based on apomorphies of the genus. Matsumoto (1915) described Proboselaphus from the Pleistocene of Sichuan, China, as a primitive form of living Boselaphus, but the holotype skull of $P$. watasei has neither cranial nor tooth characteristics of Bovidae, but rather those of Cervidae (Nishioka et al., 2018a). According to Pilgrim (1939), Sivaportax from the Neogene Irrawaddy beds of Myanmar is phylogenetically related to Boselaphus, but our recent studies indicated that the former shares horn core morphology with Miocene Tragoportacini or Stem Bovini rather than Boselaphini (Nishioka et al., 2018b). In this study, we accept that Duboisia is the only extinct genus included in Boselaphini.

Regarding cranial morphology, PPN 01-000109 has the precornual ridges extending from the anterior keels (or ridges) of the horn cores which are a synapomorphy of Boselaphini. Rugosity on the fronto-parietal surface is a symplesiomorphy of Tragoportacini (e.g. Protragocerus, Helicoportax, Tragoportax, and Miotragocerus) and Boselaphini, but
Table 1. Comparison of brain-case dimensions (in $\mathrm{mm}$ ) among boselaphins. Measuring points ( $L$, length; $W$, width; $H$, height) are shown in Fig. 3.

\begin{tabular}{crrrrr}
\hline & $L$ & $W$ & $H$ & $L / W$ & $H / W$ \\
\hline B. tragocamelus & & & & & \\
\hline BNHS 18183 & 107.2 & 81.5 & 51.6 & 1.32 & 0.63 \\
BNHS 18184 & 93.5 & 74.4 & 53.9 & 1.26 & 0.72 \\
BNHS 18186 & 89.9 & 87.9 & 52.4 & 1.02 & 0.60 \\
\hline B. namadicus & & & & & \\
\hline BMNH 36851 & 83.0 & 91.9 & 58.0 & 0.90 & 0.63 \\
BMNH M486 & 86.3 & 77.8 & 56.6 & 1.11 & 0.73 \\
\hline T. quadricornis & & & & & \\
\hline BNHS 18004 & 58.6 & 59.7 & 22.6 & 0.98 & 0.38 \\
BNHS 18125 & 63.9 & 53.7 & 19.4 & 1.19 & 0.36 \\
\hline D. santeng & & & & & \\
\hline MGB.Dbs. & 68.1 & 79.8 & 41.5 & 0.85 & 0.52 \\
\hline D. aff. santeng & & & & & \\
\hline PPN 01-000109 & 65.1 & 68.7 & 38.1 & 0.95 & 0.55 \\
\hline
\end{tabular}

that of PPN 01-000109 is finer than that of the tragoportacin genera. Moreover, PPN 01-000109 has relatively weaker temporal crests on the parietals and an antero-posteriorly shorter brain case than the tragoportacin genera listed above. According to previous studies (Stremme, 1911; Hooijer, 1958) and our observation, a combination of the following characteristics of the horn cores is diagnostic to distinguish the genus Duboisia from all of the other genera of Bovinae: the lower half inclined backwards; the upper half curved upwards; and the cross section rounded triangular, compressed antero-posteriorly, and with medial and lateral keels. Boselaphus namadicus is known as an extinct form of boselaphins from the older alluvium (Middle Pleistocene) of the Narmada basin, India (Rütimeyer, 1878; Pilgrim, 1939; Chauhan, 2008), and from the Plio-Pleistocene deposits of Sardhok, Pakistan (Siddiq et al., 2017). The horn core of the holotype (BMNH 36851) of $B$. namadicus has equilateral triangular cross section with a sharp anterior keel and is less compressed antero-posteriorly than that of PPN 01000109 or the genus Duboisia. In measurements (Table 1), the brain case of PPN 01-000109 is antero-posteriorly shorter than that of Boselaphus tragocamelus and approximately as long as that of Boselaphus namadicus or Tetracerus quadricornis based on dividing length by width. In the occipital height divided by width, PPN 01-000109 is intermediate between Boselaphus and Tetracerus. Based on the qualitative and quantitative comparisons in horn core and brain-case morphology, as mentioned above, PPN 01-000109 is distinguished from Boselaphus and Tetracerus.

The genus Duboisia formally contains two species i.e. D. santeng (Dubois, 1891) and D.? sartonoi Geraads, 1979 


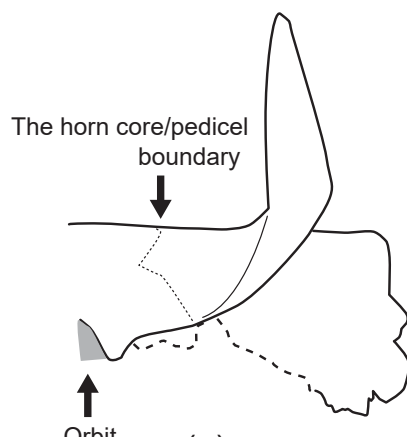

(a)

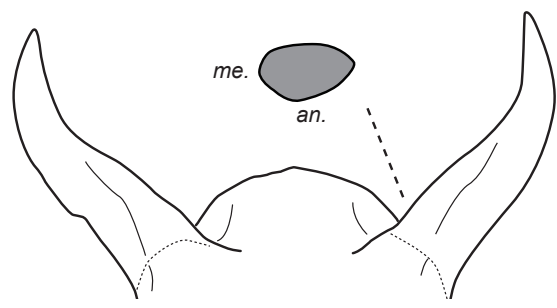

(b)
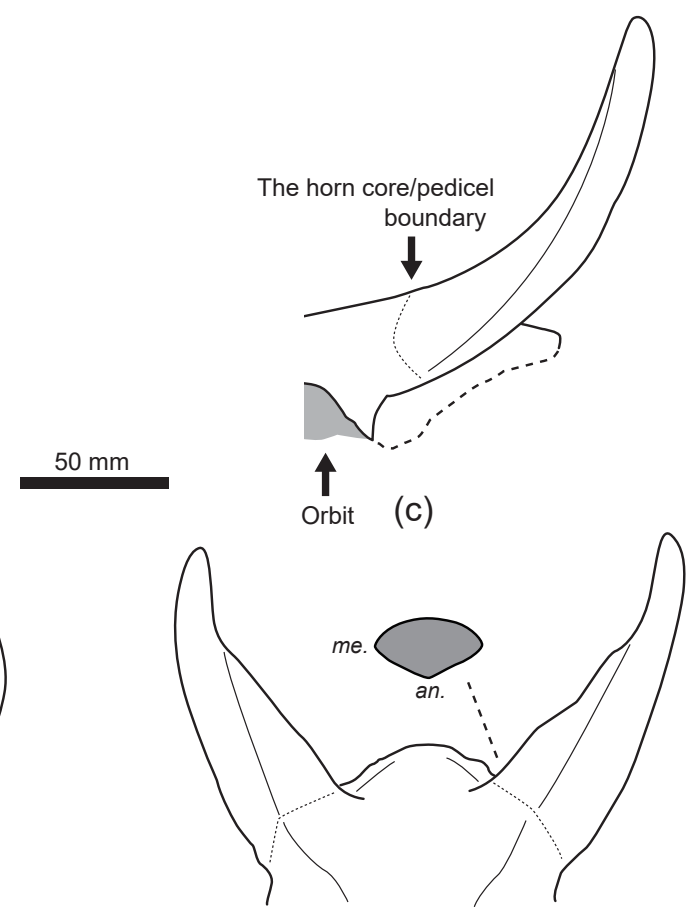

(d)

Figure 4. Comparison of skulls between Duboisia aff. santeng (A-B: PPN 01-000109) and D. santeng (C-D: MGB.SA 290709) from Pucung (Java). Panels (a) and (c), left lateral view; (b) and (d), anterior view and cross section of the left horn core. Abbreviations: an., anterior; me., medial.

(or D. saatensis Von Koenigswald, 1934), although the latter was established based on some isolated teeth. Van den Bergh (1988), in his unpublished master dissertation, suggested that Cervus problematicus Von Koenigswald, 1933, from Bumiayu, Java, should be combined with the genus Duboisia based on a large skull fragment. Both ?D. sartonoi and D. problematicus are likely larger than D. santeng, but these species are still debatable taxonomically (Rozzi et al., 2013). PPN 01-000109 is almost as large as the specimen MGB.Dbs. of D. santeng from Sangiran (Table 1). The horn cores of PPN 01-000109 are primarily similar to those of D. santeng, in having keels on the medial and lateral sides and cross section compressed antero-posteriorly, but there are some minor differences between PPN 01-000109 and D. santeng (MGB.SA 290709) from Pucung. Compared to the latter, the former has slender horn cores, curved prominently, and incomplete anterior and medial keels (Fig. 4). Moreover, precornual ridges of PPN 01-000109 are weaker than those of MGB.SA 290709. These differences of horn cores are possibly due to intraspecific variation. Although a species identification of PPN 01-000109 should be discussed in detail based on additional specimens from Thailand and comparing with a sufficient number of specimens of $D$. santeng from Java, PPN 01-000109 has a strong affinity with D. santeng.

\section{Discussion}

What Duboisia species were distributed on the continental region of southern Asia has been discussed in previous studies (Hooijer, 1962; Moigne et al., 2016), but these fossil records based only on isolated teeth are still debatable in taxonomy because cranial (and possibly dental) morphology should be diagnostic of the genus Duboisia (Stremme, 1911; Hooijer, 1958). Recently, we described an incomplete calvarium of Duboisia from an indeterminate horizon at Bagan, central Myanmar (Nishioka et al., 2018b). The present finding of $D$. aff. santeng from Thailand in conjunction with the fossil record from Myanmar confirmed the existence of Duboisia on continental South East Asia, and provides a certain fossil evidence indicating a morphological affinity of Duboisia species between continental and island South East Asia. Rozzi et al. (2013) discussed if D. santeng had been downsized and acquired unique characteristics in postcranial bones as a result of insular processes (see also Rozzi, 2018) and/or an adaptive shift to dense forest. Although we have not examined strict size and shape differences between Duboisia species from Thailand and Java, our results suggest that basic cranial characteristics of the genus Duboisia (e.g. a squared brain case, weak temporal crests and antero-posteriorly compressed horn cores with medial and lateral keels) had been 
already acquired before or at the beginning of the Early Pleistocene on continental South East Asia.

The occurrence of the genus Duboisia from Thailand supports either of the two hypotheses. If PPN 01-000109 was collected from the upper unit that includes Early Pleistocene tektites ( $0.8 \mathrm{Ma}$ by Howard et al., 2003), this age corresponds approximately with the $D$. santeng horizon on Java, or the Early-Middle Pleistocene ages of Sangiran and Trinil H.K. (ca. 0.9-0.5 Ma by Joordens et al., 2015; Falguères et al., 2016). In fact, the Pleistocene fauna share many mammalian species between continental and island regions in South East Asia (Tougard, 2001; Louys et al., 2007; Zin-Maung-MaungThein et al., 2010; Suraprasit et al., 2016). Morphological affinities between the Thai and Javanese forms of Duboisia are consistent with what existed contemporaneously in South East Asia. On the other hand, greyish sandstone and pyrite coated the surface of PPN 01-000109 (Fig. 2) are the same as those in the lower unit dated to the Miocene. If PPN 01000109 was collected from the lower unit, as most mammalian fossils from Tha Chang sandpits were (Chaimanee et al., 2004, 2007; Hanta et al., 2008; Thasod et al., 2011; Deng et al., 2013; Nishioka et al., 2014; Duangkrayom et al., 2017), undeniable morphological differences between $D$. aff. santeng and $D$. santeng should be found, which coherently explains geographical and chronological gaps of these species. At the present state, however, we have no more evidence from which horizon PPN 01-000109 was recovered.

The present study clarifies that the genus Duboisia is undoubtedly a member dispersed via the "Siva-Malayan" route and supports a low degree of endemism of the EarlyMiddle Pleistocene fauna of Java (e.g. Van der Geer et al., 2010). Bovines on the southern Asian continent were dominated by Tragoportacini (e.g. Protragocerus, Helicoportax, and Tragoportax) and Stem Bovini (Selenoportax and Pachyportax) during 9 and $6 \mathrm{Ma}$ (Gentry et al., 2014), and after the latest Miocene the Irrawaddy fauna of central Myanmar began being dominated by Irrawaddy-endemic taxa by the formation of geographical barriers, such as the Indo-Burma Range, between South Asia and South East Asia (Nishioka et al., 2018b). There is an exceptionally incomprehensible fossil record of Duboisia from the Pliocene of India (Moigne et al., 2016), but based on certain cranial fossil records of Boselaphus namadicus (Pilgrim, 1939) and Duboisia species (Nishioka et al., 2018b; this study), geographical isolation at the Indo-Burma boundary could be a possible factor explaining the divergence of Boselaphins between the South Asian lineage (Boselaphus + Tetracerus) and the South East Asian lineage (Duboisia) (Fig. 5).

\section{Conclusions}

A species of Duboisia aff. D. santeng newly discovered from a sandpit at Tha Chang, north-eastern Thailand, supports a faunal interchange between continental South East Asia and

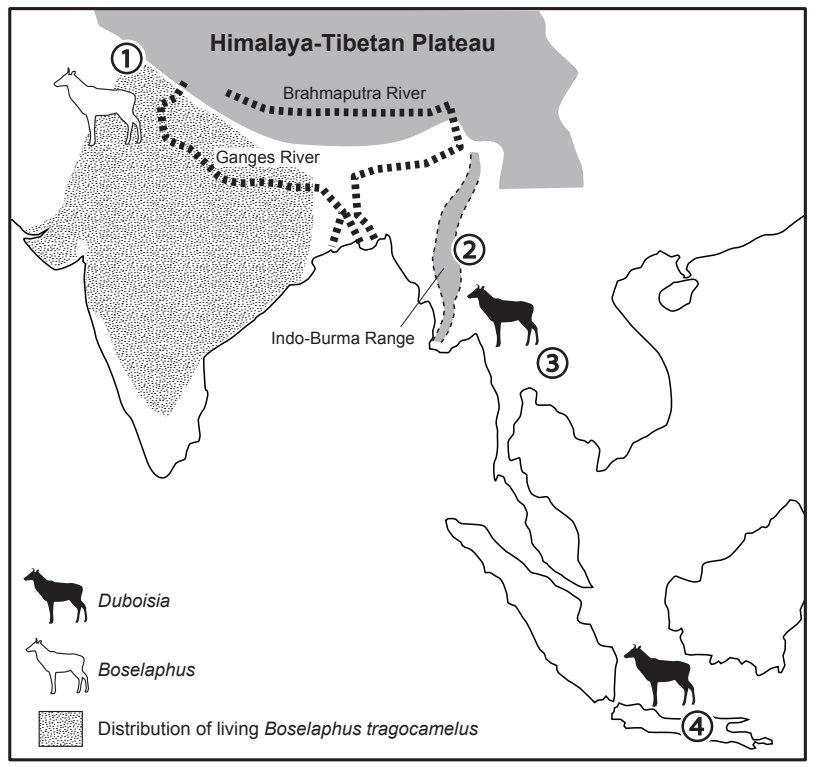

Figure 5. Distribution of Boselaphini and zoogeographical barriers between South Asia and South East Asia. Fossil localities: 1, Siwaliks; 2, Bagan; 3, Tha Chang; 4, Java.

Java before the Middle Pleistocene. The finding of Duboisia on the South East Asian continent suggests that the genus was diverged from the other Boselaphini (Boselaphus and Tetracerus) owing to a geographical isolation on the continent rather than insular processes of South East Asian islands.

Data availability. All material examined in this study is accessible in the listed institutions and all data are described in the text and table.

Author contributions. YN and CV designed this study and prepared the examined fossil material. YN prepared the manuscript with contributions from all co-authors.

Competing interests. The authors declare that they have no conflict of interest.

Acknowledgements. We thank Pratueng Jintasakul (Nakhon Ratchasima Rajabhat University, Thailand) for his helpful fossil preparation at his institute. Kamol Chaivanich (Bangkok, Thailand), Prasert Prasarttong-Osoth (CEO of Bangkok Airways and the owner of the Sukhothai Elephant World Museum, Thailand), Porpan Vachajitpan (Bangkok, Thailand) and Sakchai Juan-Ngam (Sukhothai Elephant World Museum, Thailand) kindly gave us a chance to study the present fossil material. Comparative material was obtained from the National History Museum, London (UK), the Museum Geologi Bandung (Indonesia) and from pictures by 
Tshen Tze Lim (University of Cambridge, UK). We are thankful to the helpful comments of the reviewers Roberto Rozzi and Dimitris S. Kostopoulos. The present study was financially supported in part by a Waseda University Grant for Special Research Project [2018K-462] and by the Japan Society for the Promotion of Science KAKENHI, Grant-in-Aid for Scientific Research [16K17828], [18K06444], and [18H01327].

Edited by: Johannes Müller

Reviewed by: Roberto Rozzi and Dimitris S. Kostopoulos

\section{References}

Aimi, M. and Aziz, F.: Vertebrate fossils from the Sangiran Dome, Mojokerto, Trinil and Sambungmacan areas, in: Quaternary Geology of the Hominid Fossil Bearing Formations in Java, edited by: Watanabe, N. and Kadar, D., Geological Research and Development Centre, Ministry of Mines and Energy, Indonesia, 155197, 1985.

Barry, J. C., Morgan, L. E., Flynn, L. J., Pilbeam, D., Behrensmeyer, A. K., Raza, S. M., Khan, I. A., Badgley, C., Hicks, J., and Kelley, J.: Faunal and environmental change in the late Miocene Siwaliks of northern Pakistan, Palaeobio., 18, 1-71, 2002.

Bibi, F.: Evolution, systematics, and paleoecology of Bovinae (Mammalia: Artiodactyla) from the late Miocene to the recent, PhD thesis, Yale University, USA, 469 pp., 2009.

Bibi, F., Bukhsianidze, M., Gentry, A. W., Geraads, D., Kostopoulos, D. S., and Vrba, E. S.: The fossil record and evolution of Bovidae: state of the field, Palaeont. Elect., 11 pp., 12.3.10A, 2009.

Chaimanee, Y., Suteethorn, V., Jintasakul, P., Vidthayanon, C., Marandat, B., and Jaeger, J.-J.: A new orang-utan relative from the Late Miocene of Thailand, Nature, 427, 439-441, 2004.

Chaimanee, Y., Yamee, C., Tian, P., Khaowiset, K., Marandat, B., Tafforeau, P., Nemoz, C., and Jaeger J.-J.: Khoratpithecus piriyai, a late Miocene hominoid of Thailand, Am. J. Phys. Anthropol., 131, 311-323, 2006.

Chaimanee, Y., Yamee, C., Tian, P., and Jaeger J.-J.: Diversity of Cenozoic mammals in Thailand: paleoenvironment and age updated, GEOTHAI'07 International Conference on Geology of Thailand: Towards Sustainable Development and Sufficiency Economy, 73-79, 2007.

Chauhan, P. R.: Large mammal fossil occurrences and associated archaeological evidence in the Pleistocene contexts of peninsular India and Sri Lanka, Quat. Int., 192, 20-42, 2008.

Colbert, E. H.: Fossil mammals from Burma in the American Museum of Natural History, B. Am. Mus. Nat. Hist., 74, 255-436, 1938.

Corbet, G. B. and Hill, J. E.: The mammals of the Indomalayan region, Oxford University Press, USA, 488 pp., 1992.

Deng, T., Hanta, R., and Jintasakul, P.: A new species of Aceratherium (Rhinocerotidae, Perissodactyla) from the late Miocene of Nakhon Ratchasima, northeastern Thailand, J. Vertebr. Paleontol., 33, 977-985, 2013.

Department of Mineral Resources: Geological map of Thailand; scale $1: 2,500,000$, Department of Mineral Resources, Thailand, 1999.
Duangkrayom, J., Wang, S.-Q, Deng, T., and Jintasakul, P.: The first Neogene record of Zygolophodon (Mammalia, Proboscidea) in Thailand: implications for the mammutid evolution and dispersal in Southeast Asia, J. Paleontol., 91, 179-193, 2017.

Dubois, E.: Voorloopig bericht omtrent het onderzoek naar de Pleistocene en Tertiaire vertebraten-fauna van Sumatra en Java, gedurende het jaar 1890, Natuurk. Tijdschr. Nederl. Ind., 51, 93$100,1891$.

Falguères, C., Sémah, F., Saleki, H., Hameau, S., Tu, H., Féraud, G., Simanjuntak, H., and Widianto, H.: Geochronology of early human settlements in Java: What is at stake?, Quaternary Int., 416, 5-11, 2016.

Gentry, A. W., Solounias, N., and Barry, J. C.: Stability in higher level taxonomy of Miocene bovid faunas of the Siwaliks, Ann. Zool. Fenn., 51, 49-56, 2014.

Geraads, D.: Un nouveau Bovidé (Artiodactyla, Mammalia) du Plio-Pléistocène de Java: Duboisia (?) sartonoi n. sp., B. Mus. Natl. Hist. Nat., 4, 371-376, 1979.

Gray, J. E.: On the natural arrangement of vertebrose animals, Lond. Med. Repos., 15, 296-310, 1821.

Haines, P. W., Howard, K. T., Ali, J. R., Burrett, C. F., and Bunopas, S.: Flood deposits penecontemporaneous with $\sim 0.8 \mathrm{Ma}$ tektite fall in NE Thailand: impact-induced environmental effects?, Earth Planet. Sc. Lett., 225, 19-28, 2004.

Hanta, R., Ratanasthien, B., Kunimatsu, Y., Saegusa, H., Nakaya, H., Nagaoka, S., and Jintasakul, P.: A new species of Bothriodontinae, Merycopotamus thachangensis (Cetartiodactyla, Anthracotheriidae) from the Late Miocene of Nakhon Ratchasima, Northeastern Thailand, J. Vertebr. Paleontol., 28, 1182-1188, 2008.

Hooijer, D. A.: Man and other mammals from Toalian sites in southwestern Celebes, Verh. Konin. Akad. Weten. Afd. Nat., 2, 1-164, 1950.

Hooijer, D. A.: Fossil Bovidae from the Malay Archipelago and the Punjab, Zool. Verh. Mus. Leid., 38, 1-112, 1958.

Hooijer, D. A.: Report upon a collection of Pleistocene mammals from tin-bearing deposits in a limestone cave near Ipoh, Kinta Valley, Perak, Fed. Mus. J., 7, 1-5, 1962.

Howard, K., Haines, P., Burrett, C., Ali J. R., and Bunopas S.: Sedimentology of 0.8 million year old log-bearing flood deposits in Northeastern Thailand and mechanisms for pre-flood deforestation, in: 8th International Congress on Pacific Neogene Stratigraphy, Chiang Mai, Thailand, edited by: Ratanasthien, B., Rieb, S. L., and Chantrapasert, S., 49-67, 2003.

Joordens, J. C., d'Errico, F., Wesselingh, F. P., Munro, S., De Vos, J., Wallinga, J., Ankjærgaard, C., Reimann, T., Wijbrans, J. R., Kuiper, K. F., and Mücher, H. J.: Homo erectus at Trinil on Java used shells for tool production and engraving, Nature, 518, 228231, 2015.

Lim, T. T.: Lost mammal fossils from Peninsular Malaysia, the Hooijer collection, Bull. Mus. Zool. Univ. Malaya, 1, 2-3, 2013.

Louys, J., Curnoe, D., and Tong, H.: Characteristics of Pleistocene megafauna extinctions in Southeast Asia, Palaeogeogr. Palaeocl., 243, 152-173, 2007.

McKenna, M. C. and Bell, S. K.: Classification of mammals: above the species level, Columbia University Press, USA, 631 pp., 1997.

Matsumoto, H.: On some fossil mammals from Sze-chuan, China, Sci. Rep. Tohoku Imp. Univ., 2nd Ser., Geol., 3, 1-28, 1915. 
Moigne, A.-M., Malassé, A. D., Singh, M., Kaur, A., Gaillard, C., Karir, B., Pal, S., Bhardwaj, V., Abdessadok, S., Sao, C. C., Gargani, J., and Tudryn, A.: The faunal assemblage of the paleontoarcheological localities of the Late Pliocene Quranwala Zone, Masol Formation, Siwalik Range, NW India, CR Palevol., 15, 359-378, 2016.

Nishioka, Y., Hanta, R., and Jintasakul, P.: Note on giraffe remains from the Miocene of continental Southeast Asia, J. Sci. Tech. Mahasarakham Univ., 33, 366-377, 2014.

Nishioka, Y., Takai, M., Nishimura, T., Thaung-Htike, Zin-MaungMaung-Thein, Egi, N., Tsubamoto, T., and Maung-Maung: Late Pliocene rodents from the Irrawaddy sediments of central Myanmar and their palaeogeographical significance, J. Syst. Palaeontol., 13, 287-314, 2015.

Nishioka, Y., Kohno, N., and Kudo, Y.: Taxonomic revision of the holotype of Proboselaphus watasei Matsumoto, 1915 (Bovidae, Artiodactyla) from Sichuan, China, in preparation, 2018a.

Nishioka, Y., Takai, M., Tsubamoto, T., Egi, N., Nishimura, T., Kono, R., Ogino, S., Thaung-Htike, Zin-Maung-Maung-Thein, and Vidthayanon, C.: Bovidae (Mammalia, Artiodactyla) from the Neogene Irrawaddy beds, Myanmar, Palaeontogr. Abt. A, in press, 2018b.

Owen, R.: On the archetype and homologies of the vertebrate skeleton, 1st edition, John van Voorst, Paternoster Row, London, 1848.

Pilgrim, G. E.: The fossil Bovidae of India, Palaeo. Ind., 26, 1-356, 1939.

Rozzi, R.: Space-time patterns of body size variation in island bovids: The key role of predatory release, J. Biogeogr., 45, 11961207, 2018.

Rozzi, R., Winkler, D. E., de Vos, J., Schulz, E., and Palombo, M. R.: The enigmatic bovid Duboisia santeng (Dubois, 1891) from the Early-Middle Pleistocene of Java: A multiproxy approach to its paleoecology, Palaeogeogr. Palaeocl., 377, 73-85, 2013.

Rütimeyer, L.: Die Rinder der Tertiär-Epoche nebst Vorstudien zu einer natürlichen Geschichte der Antilopen, Abh. Schweiz. Paläont. Ges., part 1, 4, 1-72 and part 2, 5, 73-208, 1978.

Saegusa, H., Thasod, Y., and Ratanasthien, B.: Notes on Asian stegodontids, Quaternary Int., 126, 31-48, 2005.

Schlosser, M.: Die fossilen Säugethiere Chinas nebst einer odontographie der recenten antilopen, Abh. Bayer. Akad. Wiss. Math.-Natur. Klas., 22, 1-221, 1903.

Siddiq, M. K., Riaz, A., Khan, M. A., Babar, M. A., Mahmood, K., and Akhtar, M.: Fossils of Boselaphus (Bovini: Bovidae: Ruminantia) from Sardhok Pleistocene of Pakistan, Pakistan J. Zool., 49, 2327-2330, 2017.

Sondaar, P. Y.: Faunal evolution and the mammalian biostratigraphy of Java, Cour. For. Senck., 69, 219-235, 1984.
Stamp, L. D.: An outline of the Tertiary geology of Burma, Geol. Mag., 59, 481-501, 1922.

Stremme, H.: Die Säugetiere mit Ausnahme der Proboscidier, in: Die Pithecanthropus-Schichten auf Java, edited by: Selenka, L. and Blanckenhorn, M., Wilhelm Engelmann, Leipzig, 82-150, 1911.

Suraprasit, K., Jaeger, J.-J., Chaimanee, Y., Chavasseau, O., Yamee, C., Tian, P., and Panha, S.: The middle Pleistocene vertebrate fauna from Khok Sung (Nakhon Ratchasima, Thailand): biochronological and paleobiogeographical implications, ZooKeys, 613, 1-157, 2016.

Takai, M., Nishioka, Y., Thaung-Htike, Maung-Maung, KyawKhaing, Zin-Maung-Maung-Thein, Tsubamoto, T., and Egi, N.: Late Pliocene Semnopithecus fossil from central Myanmar: rethinking of the evolutionary history of cercopithecid monkeys in Southeast Asia, Hist. Biol., 28, 171-187, 2016.

Thasod, Y., Jintasakul, P., and Ratanasthien, B.: Proboscidean fossil from the Tha Chang sand pits, Nakhon Ratchasima Province, Thailand, J. Sci. Tech. Mahasarakham Univ., 31, 33-44, 2011.

Tougard, C.: Biogeography and migration routes of large mammal faunas in South-East Asia during the Late Middle Pleistocene: focus on the fossil and extant faunas from Thailand, Palaeogeogr. Palaeocl., 168, 337-358, 2001.

Van den Bergh, G. D.: Duboisia santeng, the endemic Pleistocene bovid from Java (Indonesia), Master thesis, Utrecht University, the Netherlands, 72 pp., 1988.

Van den Bergh, G. D., de Vos J., and Sondaar, P. Y.: The Late Quaternary palaeogeography of mammal evolution in the Indonesian Archipelago, Palaeogeogr. Plaeocl., 171, 385-408, 2001.

Van der Geer, A., Lyras, G., de Vos, J., and Dermitzakis, M.: Evolution of island mammals, Wiley-Blackwell, UK, 479 pp., 2010.

Van der Maarel, F. H.: Contributions to the knowledge of the fossil mammalian fauna of Java, Wetensch. Meded. Dien. Mijn. Neder.-Ind., 15, 1-208, 1932.

Von Koenigswald, G. H. R.: Beitrag zur kenntniss der fossilen wirbeltiere Javas, Wetensch. Meded. Dien. Mijn. Neder.-Ind., 23, 1-127, 1933.

Von Koenigswald, G. H. R.: Zur stratigraphie des Javanischen Pleistochän, Ingen. Neder.-Ind., 1, 185-201, 1934.

Zin-Maung-Maung-Thein, Takai, M., Tsubamoto, T., Egi, N., Thaung-Htike, Nishimura, T., Maung-Maung, and Zaw-Win: A review of fossil rhinoceroses from the Neogene of Myanmar with description of new specimens from the Irrawaddy Sediments, J. Asian Eath. Sci., 37, 154-165, 2010. 